\title{
Serotonin and Melatonin Do Not Play a Prominent Role in the Growth of Prostate Cancer Cell Lines
}

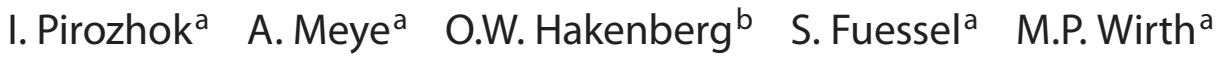 \\ a Department of Urology, Technical University of Dresden, Dresden, and bepartment of Urology, \\ University Hospital Rostock, Rostock, Germany
}

\section{Key Words}

Prostate cancer cell lines · Serotonin - Melatonin · Cellular viability $\cdot$ Apoptosis $\cdot$ Cell cycle

\begin{abstract}
Objectives: To investigate the effects of serotonin and melatonin (MLT) on the regulation of malignant growth and the activity of serotonin receptors (5HTR1a/-1b) in prostate cancer (PCa) cell lines. Materials and Methods: In four PCa cell lines (LNCaP, 22RV1, PC3, DU145) and two reference cell lines 5HTR1a and -1b, relative mRNA expression levels were assessed. Different serotonin and MLT receptor agonists and antagonists were used in stimulation and inhibition experiments. Results: mRNA expression of 5HTR1b was higher than that of 5HTR1a in all PCa cell lines. Serotonin showed a significant growth stimulatory effect in all PCa lines. The 5HTR1a and - $1 \mathrm{~b}$ agonists/antagonists did not significantly affect viability. MLT inhibited viability only in PC3 cells. Similarly, the 5HTR1a antagonist induced apoptotic changes in PC3 cells only at $10^{-4} \mathrm{M}$, while the $5 \mathrm{HTR} 1 \mathrm{~b}$ antagonist induced necrosis at $10^{-4} \mathrm{M}$ in all cell lines. Cell cycle alterations were seen in PC3 and DU145 cells under the influence of the 5HTR1a antagonist. Conclusions: Serotonin receptor antagonists and agonists as well as MLT influence viability and apoptosis of PCa cell lines at supraphysiologic concentrations. In contrast to other reports, our results do not support a regulatory role of serotonin or MLT receptor activation or inhibition in PCa growth.

Copyright $\odot 2010$ S. Karger AG, Basel
\end{abstract}

\section{Introduction}

Hormone-refractory prostate cancer $(\mathrm{PCa})$ represents the end stage of a progressive and fatal disease for which only palliative treatment options exist. Numerous concepts have been proposed to explain the biological progression of hormone-sensitive PCa to hormone-resistant PCa including stromal-epithelial interactions $[1,2]$, changes in androgen receptors [3], cell cycle machinery impairment [4], and abnormal signaling pathways [1, 58]. Currently, serotonin is considered to be of importance in the progression of $\mathrm{PCa}$ towards the hormone-refractory state $[1,9,10]$. The basis for this hypothesis is the reported expression of 5-HT receptors in LNCaP and PC 3 cell lines [5, 6]. Serotonin-mediated mitogenic activity in vitro [11] and in vivo [12] as well as effects of 5-HT agonists/antagonists have been reported $[5,6,13,14]$. 5 -HT was thus described as a potent mitogen in vitro acting in the $\mu \mathrm{M}$ concentration range and stimulating proliferation of PCa cell lines [11]. The serotonin receptor subtypes 5 HTR $1 \mathrm{a},-1 \mathrm{~b},-2 \mathrm{~b}$ and -4 were recently identified and characterized in PCa cell lines $[5,6]$. These studies, involving the administration of 5-HT agonists/antagonists in vitro reported that stimulation at low concentrations (nM to $\mu \mathrm{M}$ ) leads to increased proliferative activity, while inhibition leads to decreased proliferation in a concentration-dependent manner $[5,6,13]$. For such experiments, hormone-dependent (LNCaP), hormone-independent (PC3, DU145) and androgen-responding (22RV1)

\section{KARGER}

Fax +4161306 1234

E-Mail karger@karger.ch

www.karger.com
(C) 2010 S. Karger AG, Basel

$0042-1138 / 10 / 0844-0452 \$ 26.00 / 0$

Accessible online at:

www.karger.com/uin
Susanne Füssel, PhD

Department of Urology, Universitätsklinikum Carl Gustav Carus

Fetscherstrasse 74, DE-01307 Dresden (Germany)

Tel. +49 351458 2447, Fax +49351 4585771

E-Mail susanne.fuessel@uniklinikum-dresden.de 
human PCa cell lines are used as convenient in vitro models $[15,16]$.

The pineal hormone melatonin (MLT) may also be involved in the molecular interactions in different malignancies including PCa [2, 17-23]. Studies in LNCaP cell lines in vivo have shown an inhibition of tumor growth by MLT at nM concentrations with decreased expression of cell cycle markers [20]. It was concluded that the antiproliferative effects of MLT in LNCaP line were partly mediated by $\mathrm{MT}_{1}$ receptors and influenced the cell cycle with the possible induction of apoptotic changes [20]. The data obtained from other studies [19] on androgendeprived $\mathrm{LNCaP}$ lines also showed a direct antiproliferative effect of MLT by impairment of the cell cycle $\left(\mathrm{G}_{0} / \mathrm{G}_{1}\right.$ arrest) [21]. Results obtained from studies on MLT activity in DU145 cell lines have shown cell cycle arrest in the $\mathrm{G}_{0} / \mathrm{G}_{1}$ phase due to direct stimulation of nuclear MT receptors [23]. Membrane-associated receptors are suggested to be different sites of action of MLT in PC3 cell lines [22].

The aims of our work were to investigate the expression of two serotonin receptors (5HTRla and 5HTR1b) and the effects of serotonin, several serotonin agonists and antagonists and MLT in the regulation of malignant growth in several PCa cell lines (LNCaP, PC3, DU145, 22RV1).

\section{Materials and Methods}

\section{Cell Culture and Reagents}

The human PCa cell lines LNCaP (hormone-dependent), 22RV1 (hormone-responding), PC3 and DU145 (hormone-independent) were used for in vitro experiments (ATCC). As reference, human fibroblasts and BPH-1 cell line were used in experiments (DSMZ). The cell lines were cultivated in RPMI 1640 medium supplemented with 10\% FBS and 1\% MEM (Invitrogen, Karlsruhe, Germany) without antibiotics in $75-\mathrm{cm}^{2}$ flasks (Greiner, Frickenhausen, Germany). Cellular growth density was evaluated as low (LD; $<50 \%$ visual density) and high (HD; 50-75\% visual density). Cell counting was performed after trypsinization by Cell Coulter $Z^{2}$ Particle Count \& Size Analyzer (BeckmanCoulter, Krefeld, Germany).

Reagents used were: 5-HT, MLT (highly purified >99.5\%), ( \pm )-8-OH-DPAT (selective high-affinity 5-HTla receptor agonist), CGS-12066A maleate salt (5-HT1b receptor agonist), NAN190 hydrobromide (5-HT1a receptor antagonist), and methiothepin mesylate salt (5-HT1b receptor antagonist). All these reagents were obtained from Sigma-Aldrich, Germany.

RNA Isolation, cDNA Synthesis, Quantitative PCR

Total cellular RNA was isolated using Invisorb ${ }^{\circledR}$ Spin Cell RNA Mini Kit (Invitek GmbH, Berlin, Germany). The concentration of extracted RNA was measured by UV/Vis spectrometry on an Ultrospec 3000 (Amersham Biosciences, Little Chalfont, UK). cDNA synthesis was performed using SuperScript ${ }^{\mathrm{TM}}$ RNAse H reverse transcriptase (Invitrogen, Karlsruhe, Germany). The mRNA expression levels of the serotonin receptors $5 \mathrm{HTR} 1 \mathrm{a} /-1 \mathrm{~b}$ were measured by pre-made quantitative PCR assays (primers: Hs00265286_s1, Hs00265014_s1) and referred to housekeeping genes (HPRT - hypoxantine phosphoribosyltransferase) as internal control (Applied Biosystems, Foster City, Calif., USA) using a Light Cycler instrument (Roche, Mannheim, Germany). The RTPCR two-step program used 45 cycles of initial denaturation at $95^{\circ} \mathrm{C}$ for $600 \mathrm{~s}$; amplification 1 at $95^{\circ} \mathrm{C}$ for $15 \mathrm{~s}$; amplification 2 at $60^{\circ} \mathrm{C}$ for $15 \mathrm{~s}$; cooling at $40^{\circ} \mathrm{C}$ for $60 \mathrm{~s}$. RT-PCR products were analyzed by $2 \%$ agarose gel electrophoresis and visualized under UV after staining with ethidium bromide.

\section{Cellular Viability Test in vitro}

Cells were seeded in 96-well plates with 3,000 cells/well in $100 \mu l$ RPMI 1640 with 10\% FCS for 1 day in order to obtain optimal growth and density of no more than $75 \%$. Then, the medium was changed to $100 \mu \mathrm{l}$ RPMI 1640 with $10 \%$ charcoalstripped, hormone-free FCS (Biochrom AG, Berlin, Germany). After $24 \mathrm{~h}$ of medium adaptation, the 5HTR1a- or -1b-specific agonists at concentrations from $10^{-10}$ to $10^{-6} \mathrm{M}$ and antagonists $\left(10^{-8}\right.$ to $\left.10^{-4} \mathrm{M}\right)$ were added to the medium and incubated for 3 days. 5-HT was freshly prepared and stored in DMSO stock solutions $\left(10^{-1} \mathrm{M}\right)$ and diluted in medium to concentrations of $10^{-8}$ to $10^{-4} \mathrm{M}$. MLT was also freshly prepared and diluted in DMSO to $1.0 \mathrm{M}$ stock solution, then in medium in concentration ranges of $10^{-11}$ to $10^{-3} \mathrm{M}$ and was administered daily during 4 days of incubation. Cellular viability was studied from 24 to $72 \mathrm{~h}$ after incubation with agonists/antagonists by cell proliferation reagent WST-1 (Roche, Penzberg, Germany) comparing control cell lines incubated with DMSO. For this, $10 \mu \mathrm{l} /$ well WST-1 was added, followed by $1-1.5 \mathrm{~h}$ of incubation $\left(37^{\circ} \mathrm{C}, 5 \% \mathrm{CO}_{2}\right)$. Cell viability was determined by absorbance measurement at $450 \mathrm{~nm}$ (reference wavelength $620 \mathrm{~nm}$ ) using a microplate reader (Anthos Labtec, Krefeld, Germany). Viability after incubation with agonists/antagonists was expressed relative to control (incubated with DMSO).

\section{Cell Cycle, Apoptosis Analysis by Flow Cytometry}

Changes in cell cycle of $2 \times 10^{4}$ nuclei were analyzed using Cycle Test ${ }^{\mathrm{TM}}$ Plus DNA Reagent Kit (Becton Dickinson, Heidelberg, Germany) and FACScan (Becton, Dickinson). The early (annexin+/propidium iodide-) and late (annexin+/ propidium iodide+) apoptosis was studied by Annexin V-FITC Apoptosis Detection Kit I (BD Biosciences, Heidelberg, Germany) according to the manufacturer's instructions.

\section{Results}

\section{Basal mRNA Expression Levels of 5HTR1a and 5 HTR $1 b$ in PCa Cell Lines}

The results of the quantification of the relative mRNA expression levels of the 5HTR receptor subtypes HTR1a and HTR $1 b$ corresponding to the growth density are shown in figure 1 . Transcripts were detectable in all cell 
Fig. 1. Relative mRNA expression of 5HTR1a (a) and 5HTR1b (b) normalized to the reference gene HPRT in PCa cell lines corresponding to the growth density of the cells.

Fig. 2. Relative viability of $22 \mathrm{RV} 1, \mathrm{PC} 3$ and DU145 cell lines (normalized to control incubated with DMSO) $24 \mathrm{~h}$ after incubation with $5-\mathrm{HT}$.
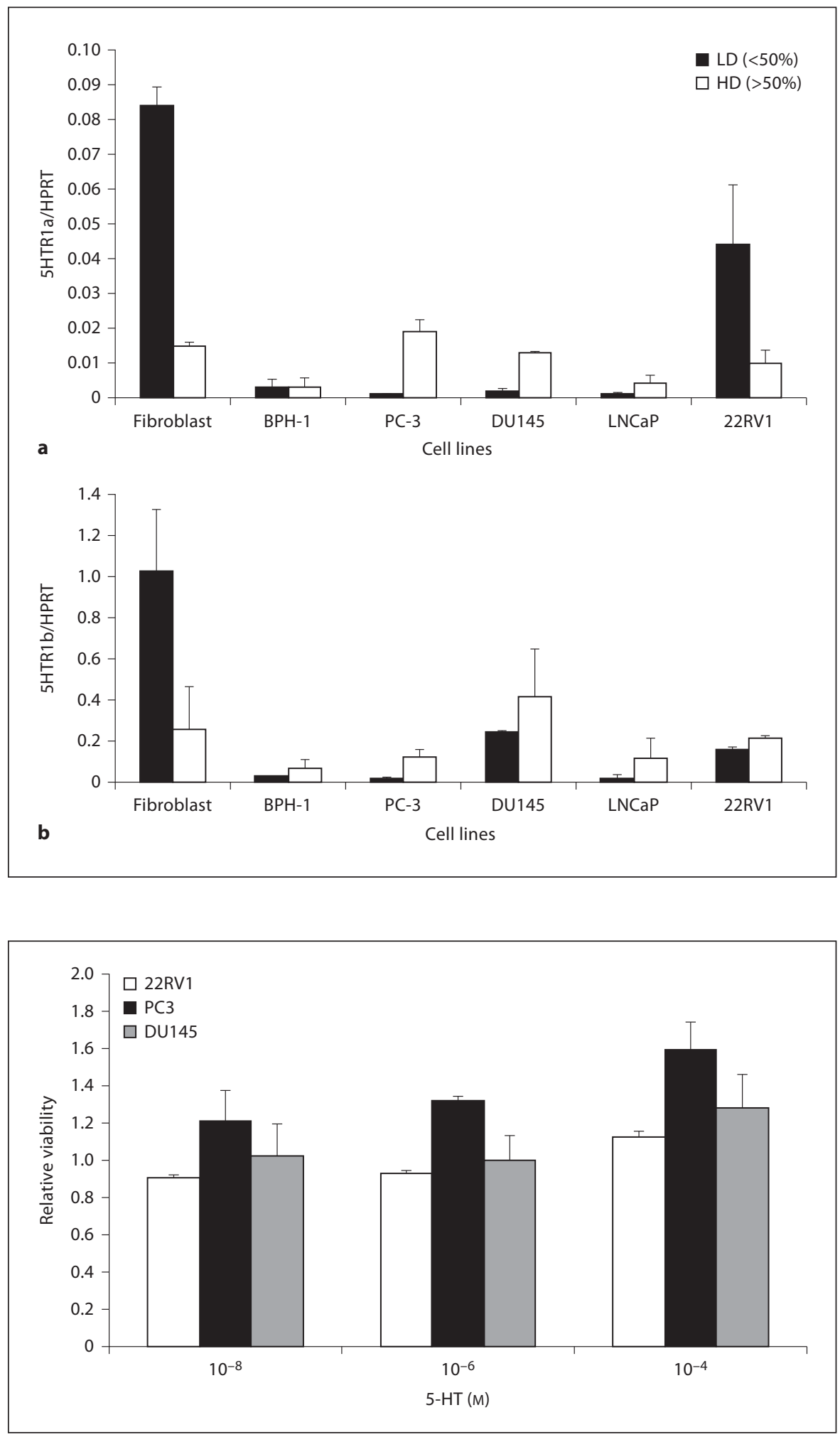
Fig. 3. Cellular viability in $\mathrm{LNCaP}(\mathbf{a}), \mathrm{PC} 3$ (b) and DU145 (c) after 48-hour incubation with NAN-190 hydrobromide and methiothepin mesylate salt in a concentration range of $10^{-8}$ to $10^{-4} \mathrm{M}$.

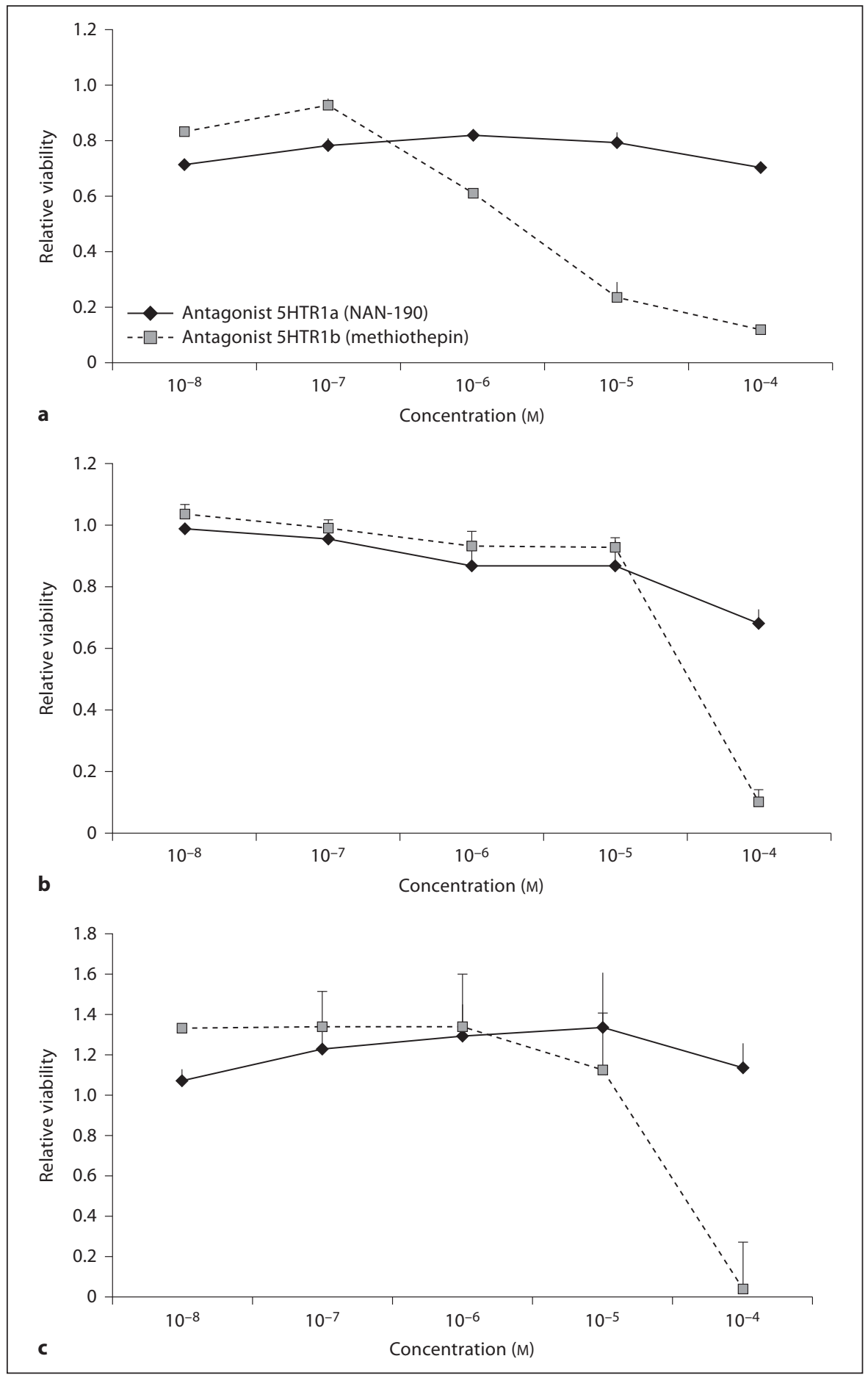

lines (data not shown). The comparison with growth density showed a higher expression of both 5HTR receptor subtypes in HD (50-75\%) compared to LD $(<50 \%)$ in all cell lines (fig. 1), with the exception of 5HTRla expression in 22RV1 and human fibroblasts.

5-HT and MLT Do Not Play a Prominent Role in PCa Cell Line Growth
Effects of 5-HT and 5HTR1a/-1b Agonists and Antagonists on Cellular Viability

The cellular viability of 22RV1, PC3 and DU145 cells after $24 \mathrm{~h}$ of incubation with $5-\mathrm{HT}\left(10^{-8}\right.$ to $\left.10^{-4} \mathrm{M}\right)$ is shown in figure 2 . The pronounced stimulatory effect 
Fig. 4. Cellular viability test (WST-1) in PC3 (a) and DU145 (b) after 24-hour incubation with NAN-190 hydrobromide and methiothepin mesylate.

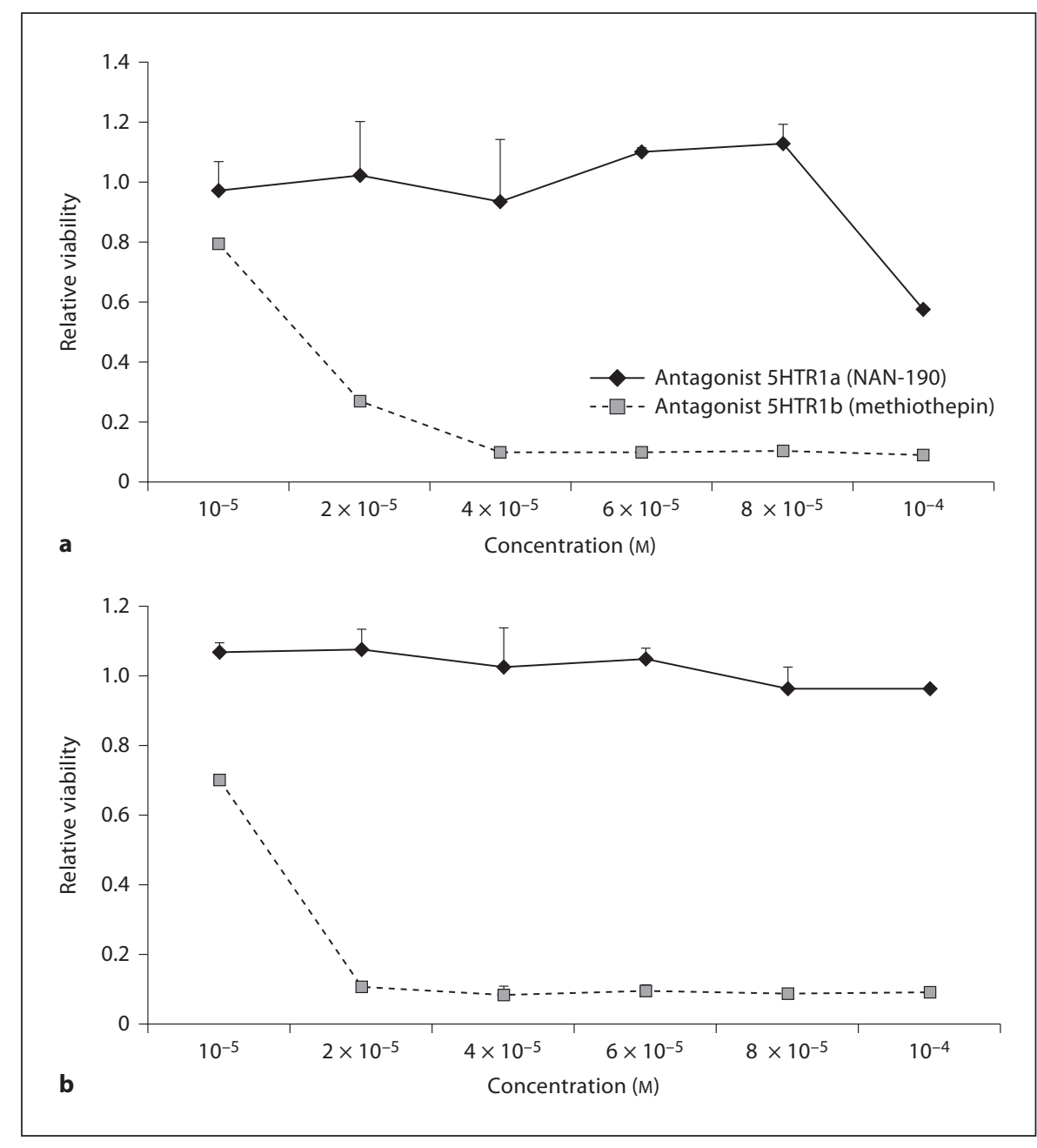

with increased cellular growth was observed in PC3 cells $\left(+21.2,+31.8\right.$ and $+59.5 \%$ at $10^{-8}, 10^{-6}$ and $10^{-4} \mathrm{M}$, respectively). In DU145 cells, a slight stimulatory effect was observed only at $10^{-4} \mathrm{M}(+28.2 \%)$. LNCaP and 22RV1 cells did not respond at all to 5-HT stimulation (data not shown). Figure 3 gives the results of cell viability assessment without 5-HT stimulation in the presence of the 5HTla antagonist NAN-190 hydrobromide or the 5-HT1b antagonist methiothepin mesylate. After $48 \mathrm{~h}$ of incubation, cellular viability was not affected by the antagonist in the concentration range of $10^{-8}$ to $10^{-5} \mathrm{M}$. At a concentration of $10^{-4} \mathrm{M}$, no changes were observed after 5HTR1a inhibition. A concentration of $10^{-4} \mathrm{M}$ of methiothepin mesylate was cytotoxic and caused total necrosis after $12 \mathrm{~h}$ of incubation. A 24-hour incubation of the cell lines PC3 and DU145 after $24 \mathrm{~h}$ with NAN-190 and methiothepine mesylate in a constricted concentration range between $10^{-5}$ and $10^{-4} \mathrm{M}$ confirmed these results (fig. 4). Methiothepine mesylate at a concentration of $>10^{-5} \mathrm{M}$ induced dramatic cell death. In the same experiments using the 5HTR $1 \mathrm{a}$ and $-1 \mathrm{~b}$ agonists $( \pm)-8-\mathrm{OH}-\mathrm{DPAT}$ and CGS-12066A, maleate salt did not affect cellular viability (data not shown).

\section{Effects of 5HTR1a/-1b Antagonists on Apoptosis}

In DU145 cells, significant apoptotic changes were observed after 24-hour incubation with NAN-190 at a concentration of $10^{-4} \mathrm{M}$. The changes were significant for early and late apoptosis. Incubation with NAN-190 did not induce apoptosis, but necrosis in PC3 cell culture was seen at a concentration of $10^{-4} \mathrm{M}$ (fig. 5).

\section{Changes in Cell Cycle Phases after Incubation with 5HTR1a/-1b Antagonists}

Figure 6 summarizes the effects seen on cell cycle. In PC3 and DU145 cell lines, the highest proportion of cells which underwent $G_{0}-G_{1}$ phase arrest were detected after 
Fig. 5. Effects of NAN-190 on apoptosis after 24-hour incubation in DU145 (a) and PC3 (b).

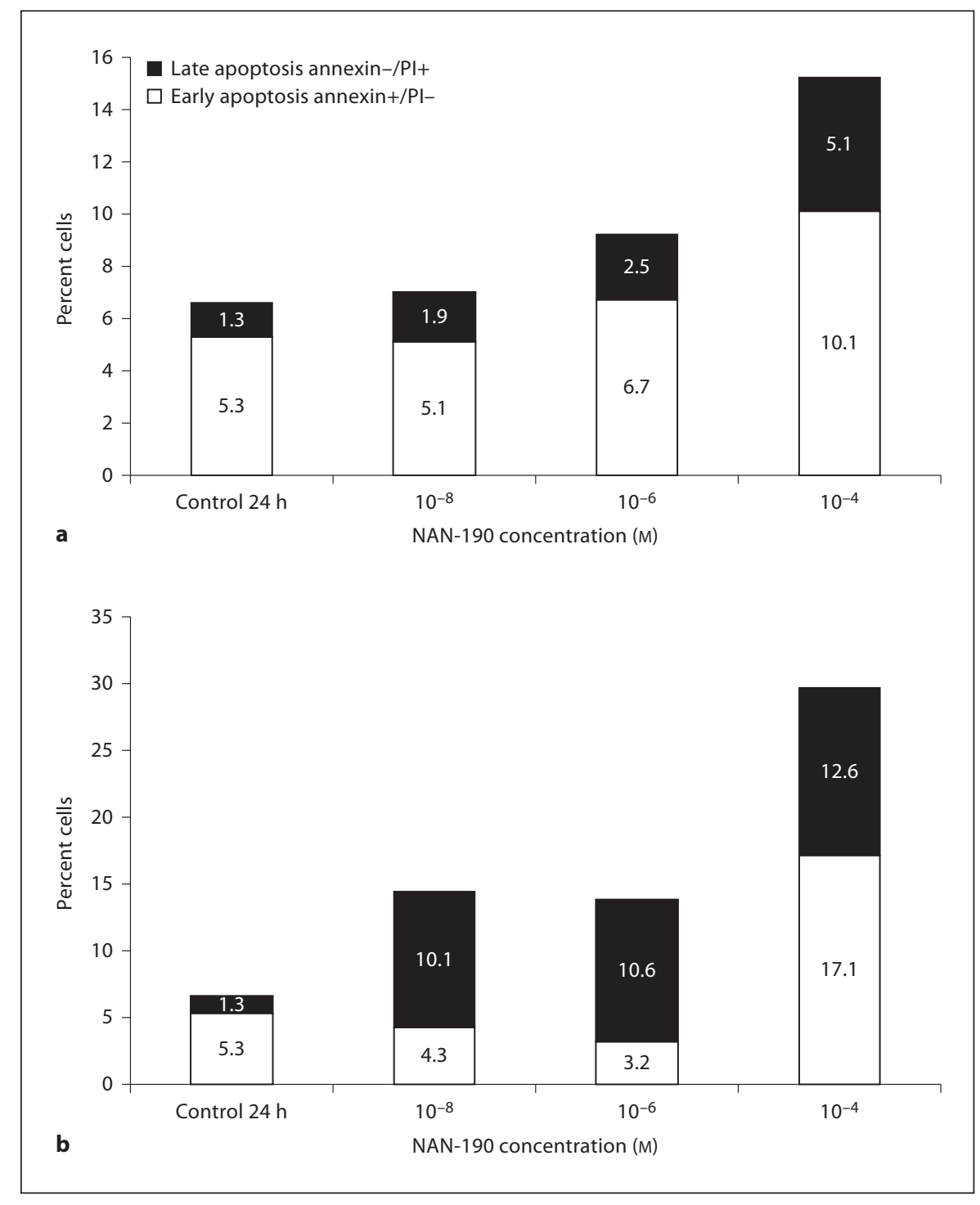

$24 \mathrm{~h}$ of incubation with the 5HTR1a antagonist (NAN190) at a concentration of $10^{-4} \mathrm{M}$ (fig. 6). Methiothepin caused no significant changes in cell cycle phases (data not shown).

\section{Effects of MLT on Cellular Viability}

Treatment of PC3, DU145 and 22RV1 cells with MLT showed time- and dose-dependent effects on cellular viability in supraphysiologic concentrations only (fig. 7). After $72 \mathrm{~h}$ of incubation with MLT in the concentration range $10^{-8}$ to $10^{-3} \mathrm{M}$, no inhibitory effects were observed (data not shown), while at supraphysiologic concentrations of MLT $\left(10^{-3}\right.$ to $\left.10^{-2} \mathrm{M}\right)$ a marked concentration-dependent decrease in cellular viability was seen (fig. 7).

5-HT and MLT Do Not Play a Prominent Role in PCa Cell Line Growth

\section{Discussion}

PCa progression remains a complex process which still evades complete understanding. Many biologic factors capable of influencing or regulating cell growth have been implicated and probably are involved [24, 25]. MLT has been shown to have an influence on cancer cell growth in several cancer entities including PCa cells growing in vitro $[26,27]$. There may even been potential therapeutic implications for MLT [28]. All these reasons make MLT a substance of interest in PCa research, and we therefore undertook these experiments on MLT receptors in PCa cell lines. We found an expression of both 5HTR subtypes 5HTR1a and 5HTR1b in the four PCa cell lines used (PC3, DU145, 
Fig. 6. Cell cycle arrest in $\mathrm{G}_{0} / \mathrm{G}_{1}$ in DU145 (a) and PC3 (b) cells after 24-hour incubation with NAN-190. Percentages of cells in different phases of the cell cycle $\left(G_{0} / G_{1}, S\right.$, $\left.\mathrm{G}_{2} / \mathrm{M}\right)$ are shown. Control refers to incubation with DMSO.

Fig. 7. Cellular viability test in PC3, DU145 and 22RV1 after 72-hour incubation with MLT in a concentration range of $10^{-3}$ to $10^{-2} \mathrm{M}$.
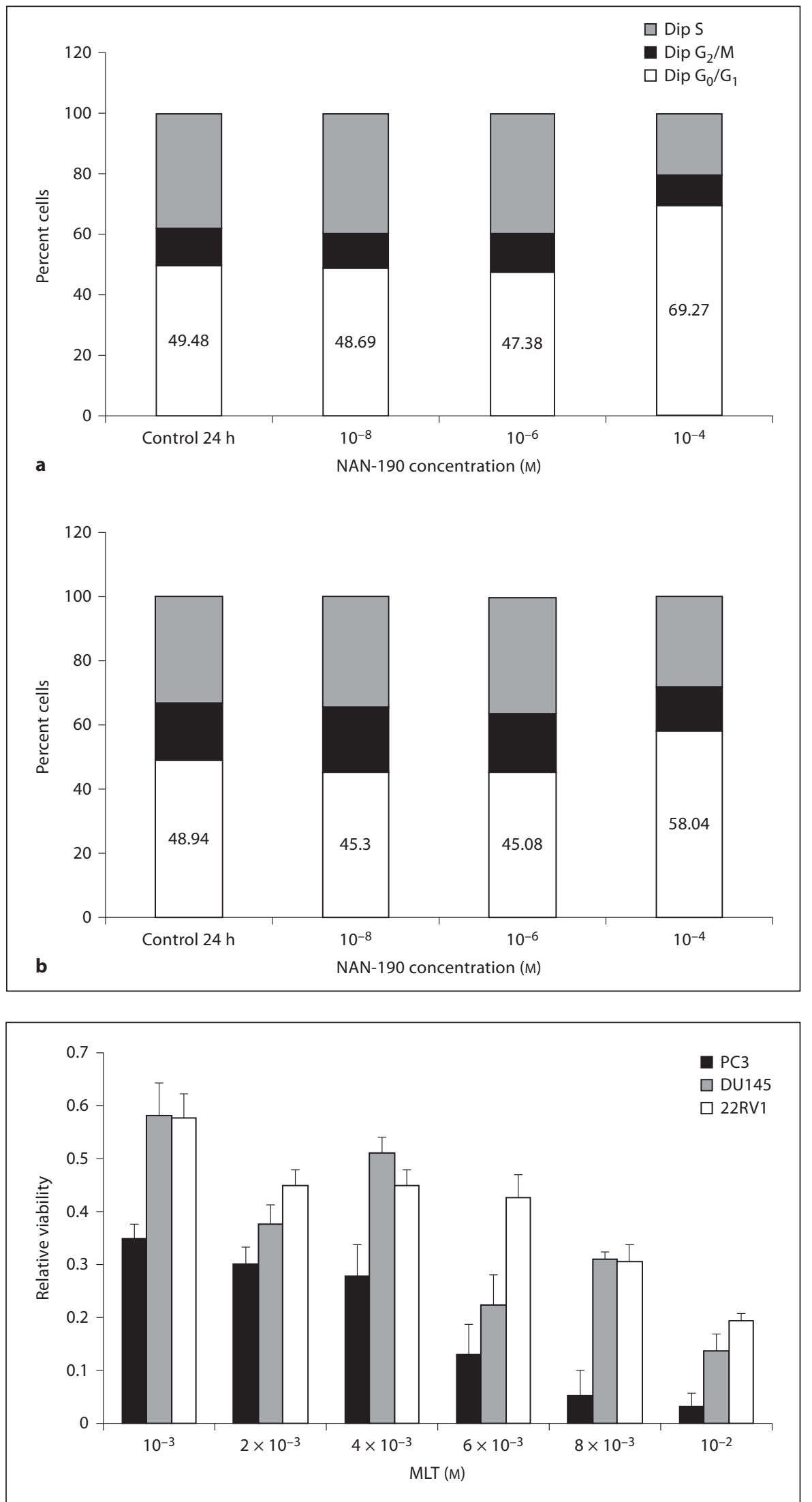
LNCaP and 22RV1) as well as in the BPH-1 line and human fibroblasts. The relatively low expression of 5HTR1a and 5HTR $1 \mathrm{~b}$ receptors observed, however, may signify that in nonstimulated PCa cells the 5HTR1a/-1b expression at mRNA level does not play a significant role in regulation of growth. Reports in the literature [5] described the qualitative (detected by PCR) and immunohistochemical features of 5HTR1a/-1b, but their functional activity may well depend on the quantitative properties.

In experiments with 5-HT stimulation, we found that the stimulatory effect was dose-dependent at $10^{-8}$ to $10^{-4} \mathrm{M}$ during the first $24 \mathrm{~h}$ and highest at $10^{-4} \mathrm{M}$. The data from the Malmö group described a stimulatory effect of 5 - HT on proliferation in DU145 and PC3 cells at $10^{-8} \mathrm{M}$ with no significant effect on LNCaP cells [5]. These and other authors describe $5-\mathrm{HT}$ as a mitogen in vitro $[5,11$, 12]. It is possible that with low $5 \mathrm{HTR} 1 \mathrm{a} /-1 \mathrm{~b}$ expression and high concentrations of 5-HT, the viability and proliferation effects may be mediated by other types of serotonin receptors as other types of serotonin receptors in PCa cell lines have been identified (5HTR2b, 5HTR4) with a putative role in proliferation and differentiation [6].

Our results with 5HTR1a/-1b agonists did not show any effect of selective 5 HTR1a/-1b stimulation on physiological concentrations. This fact may also support the low functional activity of 5HTR1a/-1b receptor subtypes. The inhibition experiments showed physiological effects on cellular viability in the concentration range $10^{-8}$ to $10^{-4} \mathrm{M}$, and only cytotoxic effects of methiothepin at $10^{-4} \mathrm{M}$. Our data suggest that inhibition of 5HTR1a/- $1 \mathrm{~b}$ in physiologic concentrations does not affect cellular viability. In contrast to our findings, other authors [5] have reported that 5HTR1a inhibition in DU145, PC3 and LNCaP cells was concentration-dependent and maximal at $10^{-6} \mathrm{M}$. However, neither those nor our results support a prominent functional role of $5 \mathrm{HTR} 1 \mathrm{a} /-1 \mathrm{~b}$ or $5-\mathrm{HT}$ stimulation in cell viability in PCa cell lines.

In agreement with others, we did find a time- and dose-dependent effect of MLT on cellular viability in PC3, DU145 and 22RV1 [22, 23]. In contrast to a hypothesis reported in the literature, this effect in our observation did not seem to be related to hormone dependency of the cell lines $[19,20,26]$. Reported maximum MLT inhibitory activity was at high concentrations of $10^{-3}$ to $10^{-2} \mathrm{M}$ after $72 \mathrm{~h}$ of continuous incubation [26], making MLT a potent inhibitor in vitro only in $\mathrm{mM}$ concentrations with effects only after prolonged incubation. Our data correspond to these reported findings concerning concentration range and time effect as well as more effective inhibition in moderate cellular density $(3,000$ cells/well) [26]. These findings thus somewhat characterize MLT as an antiproliferative agent in PCa cell lines, but may cast doubt on the hypothesis that this effect is highly specific and of great biological significance in PCa.

Similarly, while a putative role of MLT in apoptosis is still controversial, we have observed an apoptotic effect of MLT in DU145 and PC3 only at concentrations of $10^{-4} \mathrm{M}$. Since MLT as a pineal hormone exerts its biological effect in vivo at nM concentrations $[17,18]$, the observed apoptotic effect in cell culture is highly unlikely to be specific.

Changes in cell cycle due to $G_{0} / G_{1}$ phase arrest were described as one of several possible mechanisms in the regulation of proliferation [4]. We observed a $G_{0} / G_{1}$ phase arrest induced by the 5HTR1a receptor antagonist NAN190 after $24 \mathrm{~h}$ of incubation at $10^{-4} \mathrm{M}$ in PC3 and DU145 cells. Again, the concentration at which this effect was observed does not support a biological significance.

\section{Conclusions}

Our results do not support the hypothesis that activation or inhibition of the serotonin receptor subtypes 5HTR1a or 5HTR 1 b plays a prominent role in the control of growth and viability of PCa cell lines. Inhibitory effects of MLT in PCa cell lines in vitro occur at supraphysiological concentrations only. Thus, neither MLT nor the serotonin receptor subtypes 5HTRla and 5HTR1b seem to have an important role in the in vitro growth regulation of human PCa cell lines.

\section{Acknowledgments}

I.P. thanks European Urology Scholarship Program for providing the generous grant (S-02-2004) which supported this research during 2004-2005. The authors thank A. Lohse and S. Tomasetti for their excellent technical assistance and support.

References

Urol Int 2010;84:452-460 459
Chung LWK, Baseman A, Assikis V, Zhau H Molecular insights into prostate cancer progression: the missing link of tumor microenvironment. J Urol 2005;173:10-20.

$\checkmark 2$ Sofikerim M, Eskicorapc S, OruçÖ, Özen H: Hormonal predictors of prostate cancer. Urol Int 2007;79:13-18.

3 Shi XB, Ma AH, Tepper CG, Xia L: Molecular alterations associated with LNCaP cell progression to androgen independence. Prostate 2004;60:257-271. 
4 Maddison LA, Huss WJ, Barrios RM, Greenberg NM: Differential expression of cell cycle regulatory molecules and evidence for a 'cyclin switch' during progression of prostate cancer. Prostate 2004;58:335-344.

5 Dizeyi N, Bjartell A, Nilsson E, Hansson J, Gadaleanu V: Expression of serotonin receptors and role of serotonin in human prostate cancer tissue and cell lines. Prostate 2004;59: 328-336.

6 Dizeyi N, Bjartell A, Heldlund P, Tasken KA: Expression of serotonin receptors $2 \mathrm{~B}$ and 4 in human prostate cancer tissue and effects of their antagonists on prostate cancer cell lines. Eur Urol 2005;47:895-900.

-7 Cindolo L, Cantile M, Vacherot F, Terry S, de la Taille A: Neuroendocrine differentiation in prostate cancer: from lab to bedside. Urol Int 2007;79:287-296.

$\checkmark 8$ Froehner M, Hakenberg OW, Wirth MP: Molecular therapy in urologic oncology. Urol Int 2007;79:1-7.

9 Bonkhoff H, Fixemer T: Neuroendokrine Differenzierung im Prostatakarzinom. Ein unerkannter und therapierefraktärer Phänotyp. Urologe 2004;43:836-842.

10 di Sant'Agnese PA: Neuroendocrine differentiation in prostatic carcinoma: an update. Prostate Suppl 1998;8:74-79.

- 11 Seuwen K, Pouyssegur J: Serotonin as a growth factor. Biochem Pharmacol 1990;39: 958-990.

12 Vicaut E, Laemmel E, Stucker O: Impact of serotonin on tumour growth. Ann Med 2000;32:187-194.
13 Abdul M, Anezinis PE, Logothetis CJ, Hoosein NM: Growth inhibition of human prostatic carcinoma cell lines by serotonin antagonists. Anticancer Res 1994;14:12151220.

14 Abdul M, Logothetis CJ, Hoosein NM: Growth-inhibitory effects of serotonin uptake inhibitors on human prostate carcinoma cell lines. J Urol 1995;154:247-250.

15 Sobel RE, Sadar MD: Cell lines used in prostate cancer research: a compendium of old and new lines - part 1. J Urol 2005;173:342359.

16 Sobel RE, Sadar MD: Cell lines used in prostate cancer research: a compendium of old and new lines - part 2. J Urol 2005;173:360 372.

17 Bartsch C, Bartsch H: Significance of melatonin in malignant diseases (in German). Wien Klin Wochenschr 1997;109:722-729.

18 Karasek M, Pawlikowski M: Pineal gland, melatonin and cancer. NEL Review. Neuro Endocrinol Lett 1999;20:139-144.

19 Siu SWF, Lau KW, Tam PC, Shiu SY: Melatonin and prostate cancer cell proliferation: interplay with castration, epidermal growth factor, and androgen sensitivity. Prostate 2002;52:106-122.

20 Xi S, Siu SWF, Fong SW, Shiu SYW: Inhibition of androgen-sensitive LNCaP prostate cancer growth in vivo by melatonin: association of antiproliferative action of the pineal hormone with $\mathrm{mt} 1$ receptor protein expression. Prostate 2001;46:52-61.
21 Moretti RM, Marelli MM, Maggi R, Dondi D, Motta M, Limonta P: Antiproliferative action of melatonin on human prostate cancer LNCaP cells. Oncol Rep 2000;7:347-351.

22 Gilad E, Laufer M, Matzkin H, Zisapel N: Melatonin receptors in PC3 human prostate tumor cells. J Pineal Res 1999;26:211-220.

-23 Marelli MM, Limonta R, Maggi M, Motta M, Moretti RM: Growth-inhibitory activity of melatonin on human androgen-independent DU 145 prostate cancer cell lines. Prostate 2000;45:238-244.

-24 Schmid HP, Gregorin J, Altwein JE: Growth hormone inhibitors in prostate cancer: a systematic analysis. Urol Int 2008;81:17-22.

25 Yan TZ, Jin FS, Xie LP, Li LC: Relationship between glucocorticoid receptor signal pathway and androgen-independent prostate cancer. Urol Int 2008;81:228-233.

26 Sainz RM, Mayo JC, Tan DX, León J, Manchester L, Reiter RJ: Melatonin reduces prostate cancer cell growth leading to neuroendocrine differentiation via a receptor and PKA independent mechanism. Prostate 2005;63:29-43.

27 Hevia D, Sainz RM, Blanco D, Quirós I, Tan DX, Rodríguez C, Mayo JC: Melatonin uptake in prostate cancer cells: intracellular transport versus simple passive diffusion. J Pineal Res 2008;45:247-257.

28 Srinivasan V, Spence DW, Pandi-Perumal SR, Trakht I, Cardinali DP: Therapeutic actions of melatonin in cancer: possible mechanisms. Integr Cancer Ther 2008;7:189203 